\title{
脳性麻痺とアキレス腱反射
}

長崎県立整肢療青園

$\begin{array}{llll}\text { 朝 } & \text { 長 } & & \text { - } \\ \text { 松 } & \text { 下 } & \text { 明 } & \text { 成 } \\ \text { 近 } & \text { 藤 } & \text { 晴 } & \text { 彦 } \\ \text { 菅 } & \text { 井 } & & \text { 治 }\end{array}$

長崎大学整形外科（主任：永井三郎教授）

$\begin{array}{lllll}\text { 玉 } & \text { 置 } & \text { 拓 } & \text { 夫 } \\ \text { 森 } & \text { 貞 } & \text { 近 } & & \text { 見 } \\ \text { 稞 } & \text { 山 } & \text { 富 } & \text { 郎 }\end{array}$

\section{Cerebral Palsy and Achilles Reflex}

By

\section{H. Tomonaga, A. Matsushita, H. Kondo \\ \& O. Sugai \\ Nagasaki Prefecture Crippled Children's Hospital}

\section{T. Tamaki, C. Morisada \& T. Akiyama}

Department of Orthopedic Surgery, Nagasaki University, School of Medicine

\section{序}

腱反射は $\mathrm{H}$ 反射と同じく単シナプス反射の一種であ るが，直接receptorを刺激することにより誘発される 点がH反射と異つている，従つて receptor自体の機能 をむ含めて, 複雑な修飾を中枢性, 末梢性に脊䯣反射 機能の様相を, 腱反射によつて知り, それより中枢性 control の側面を推測し得る可能性がある．そこで我 々はアキレス腱反射を誘発することにより生ずる下腿 三頭筋 T波を示標として, 種々なる検索を行い, 正常 者之対比しつつ, CPに扔ける脊䯣反射機能の動態を検 討した。

\section{実 験 方 法}

検査対象は正常群 5 才から 12 才までの健康児 21 例 を，CP群6才から17才までのCP児44例を選えだ。体 位は腹臥位とし, 顔面は検查肢の反刘側を向かせた。 検查肢は正常群では足関節90 100度, 膝関節145 170 度，CP群では足関節90〜130度，膝関節135１70度に

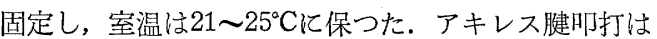
打腱器を製作，重鍾24.8～37.6gr. を85～90 cmの高さ より金属棒を通して落下させ. $1 \mathrm{~kg}$ 内外の衝撃が加わ るようにした。

誘導には三栄測器製筋電計を用い，単掃引及び刺激 時点記録にはフリップ・フロップ回路を有する装置を 自作した，活動電位の導出には直径 $1 \mathrm{~cm}$ の円形銀板 を 2 個, 筋腹中央部皮膚上筋肉の走行に沿つて $3 \mathrm{~cm}$ の間隔でゴムバンド固定した。記録にはブラウン管映 像を $88 \mathrm{~mm} \times 25 \mathrm{~m}$ のオシロペーパーに撮影した.

\section{実 験 成 績}

\section{T 波 (下腿三頭筋)}

i）波形及び持続時間

正常群では 2 相性を示し, 持続時間は 8 17msec. の 笧囲にあり， $\mathrm{CP}$ 群では2 3相性を示し，持続時間は 8〜20msec. の範囲にあつた.

ii) 振 巾

正常群では平均値0.63mVで $2 \mathrm{mV}$ 越えるむのはな 
いが， $\mathrm{CP}$ 群では平均值が $2.0 \mathrm{mV}$ で一般に高く, 最高 8. 85mVの活動電位を示すむのがあつたが， athetoid type (以下A型) は rigospastic (以下RS型) 飞比し, 振巾が小さい傾向にある.

CP群に打いて, Stoffel, Baker, アキレス腱延長術 等の手術を受けた者む, 術式の如何や術後の年数にか かわらず，非手術群同様高い振巾を示している，振巾 の動摇性については, 正常群とCP群との間に有意の差 を認めなかつた。

\section{iii）応答時}

正常群では平均 $25.1 \mathrm{msec}$. (19.5 29.2msec.).CP 群では平均23.8msec. (19.8 28.8msec.)でCP群が短 い.しかしてれでは各個人の神経径路に長短があり， 厳密には比較出来ないので平均応答速度なるものを設 定し，少しでもその差をなくしょうとした，後に述へ る大腿四頭筋への放散の場合についてあ同様である.

即ち, 下腿三頭筋の平均応答速度 $=\frac{\mathrm{a} \times 2}{\mathrm{c}}(\mathrm{m} / \mathrm{sec}$. $)$

大腿四頭筋の平均応答速度 $=\frac{a+b}{d}(\mathrm{~m} / \mathrm{sec})$.

$\mathrm{a}$ : 下腿三頭筋の電極よりDW XII棘突起までの皮虞 上の距離

$\mathrm{b}:$ 大腿四頭筋の電極より DW X 棘突起までの皮膚 上の距離

$\mathrm{c}$ : 打腱時より下腿三頭筋に 活動電位が導出される までの時間（腱反射応答時）

$d$ : 打腱時より大腿四頭筋に活動電位が導出される までの時間

乙の平均応答速度でも正常群平均值 $51.1 \mathrm{~m} / \mathrm{sec} ., \mathrm{CP}$ 群平均值 $53.2 \mathrm{~m} / \mathrm{sec}$.で CP群がわずかに速いととがわ かる. このととについては色々考元られるが，てれだ けのデータでは決定的なととは云えないようである (図 1 ).

\section{II. アキレス腱反射に対する Jendrassik氏手技の影}

アキレス腱反射誘発時に Jendrassik 氏手技を行わ せたむの（J.と略す）とそうでないむの(F.之呼ぶ)の 振巾の比をとり, 反射の増強の割合を調べた.
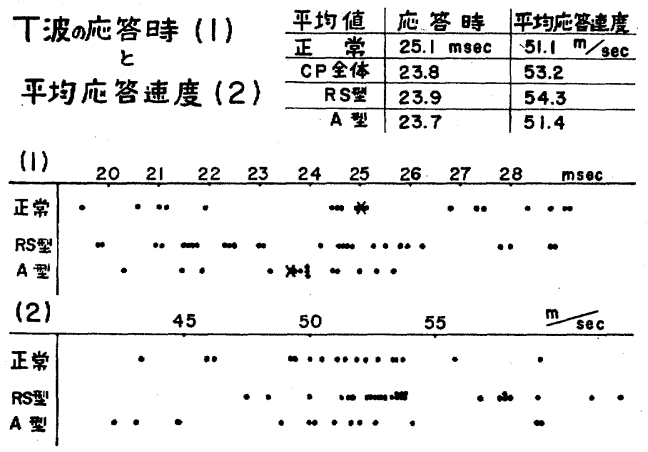

図 1

$\frac{\mathrm{J}}{\mathrm{F}}=\frac{\mathrm{J} \text { における振巾 }}{\mathrm{F} \text { におるる振巾 }}$

正常群ではその大部分が1 3倍（平均2.83）のとこ ろに分布したが，CP群では1 2倍 (平均1.53) のとこ ろに分布し， CP群では増強の割合が低下している，特 にRS型に関してはJ.を行う以前に, 即ちF.飞おいてす でに振币が高く，発射している前柱細胞か増加してい るためと思われる．A型ではJ.以前の振巾も低く $\mathrm{J} / \mathrm{F}$ も低くなつている．この検査はCP群では, Jendrassik 手技が可能なむのだけに行つた（図2，表1）.

T波(Triceps surae) の $\mathrm{J} / \mathrm{F}$

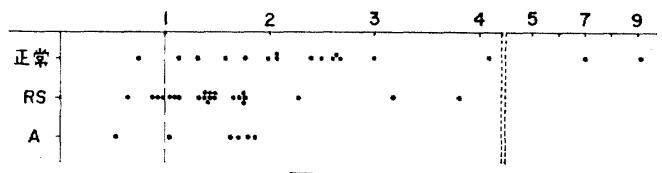

図 2

\section{III. 脛骨神経遮断の影響}

$0.5 \%$ 塩酸プロカイン 4 10ccで膝宫中央部において 脛骨神経をblockした。乙九机線維を選択的に遮断す る目的で行つたむので，その示標は困難であるが，一 応踵部にhypalgesiaが起つた時をむつてした。

まずblock前後の差及び比を調べてみると, 正常群で は1例を除き，block後，振巾の上昇せるものはない. CP群においても大部分が， block 後振巾の減少を示し ているが, rigidity の強い4例に扔いて増加している

表 1

\begin{tabular}{|c|c|c|c|c|c|c|c|c|}
\hline & & 平均 & $1 \geqq$ & $1<$ & $2<$ & $3<$ & $4<$ & 計 \\
\hline $\begin{array}{l}\text { 正 } \\
\text { C P } \\
\text { R S } \\
\text { A }\end{array}$ & $\begin{array}{l}\text { 常 } \\
\text { 全体 } \\
\text { 型 } \\
\text { 型 }\end{array}$ & $\begin{array}{l}2.83 \\
1.53 \\
1.56 \\
1.41\end{array}$ & $\begin{array}{l}1(6 \%) \\
5(17 " \prime) \\
4 \\
1\end{array}$ & $\begin{array}{c}5(29 \%) \\
21(72 " \prime) \\
16 \\
5\end{array}$ & $\begin{array}{l}7(41 \%) \\
1(4 \prime \prime) \\
1 \\
0\end{array}$ & $\begin{array}{l}1(6 \%) \\
2(7 \prime \prime) \\
2 \\
0\end{array}$ & $\begin{array}{l}3(18 \%) \\
0 \\
0 \\
0\end{array}$ & $\begin{array}{cc}17 \text { 例 } & (100 \%) \\
29 & (100 " 11) \\
23 & \\
6 & \end{array}$ \\
\hline
\end{tabular}


のは興味深い. 次にこのような状態において，さきと 同様 $\mathrm{J} / \mathrm{F}$ を出し，block直前の $\mathrm{J} / \mathrm{F}$ と比較してみた．正 常例 9 例中 8 例は block 前後に执いて J.の効果が認め られた. CP群では14例中block前後に効果があつたす の 5 例, block前効果があつてblock後になくなつたも の 4 例, block前に効果なく, block後効果があつたも の2例, block前後に効果のなかつたもの3例である.

J. 法の効果が block の前後いずれにあある症例の存在 すること, 及びblock前効果なくblock後に效果が出て くるものがあることは, J. 法にはr系以外の機構も関 与している屯のと考えられ，CP児の腱反射増強機序に は複雄なものがあると考えられる.

\section{IV. アキレス腱反射による下腿三頭筋の張力}

アキレス腱反射誘発時, 同時に下腿三頭筋のみかけ 上の張力を strain gauge で測定しペン書き記録器に 描記した. T波の振巾とこのみかけ上の張力の比をと

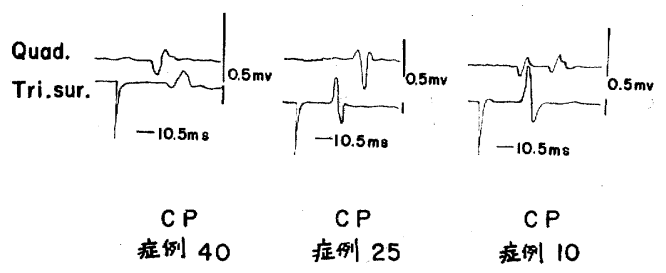

図3 (a) Tri. sur. とQuad. の活動電位

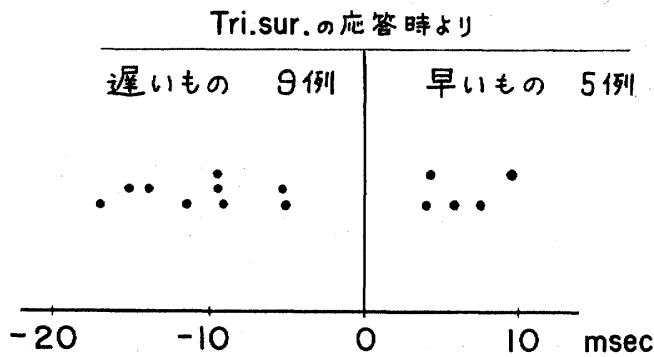

図 3(b) Tri. sur. とQuad, の応答時の差
つてみたが, 両者に予期せる比例関係を認め得なかつ た. みかけ上の張力平均值は正常群で $793 \mathrm{gr} \mathrm{CP}$ 群で は1, 075grであつた。 T波と張力との相関関係に関し ては今後の検討が必要である.

\section{V. 大腿四頭筋への放散}

大腿四頭筋と下腿三頭筋に同時に表面電極をはり， アキレス腱吒打により発生する活動電位を導出した。 正常群では放散はないか，あつても痕跡程度であつ た. CP群では44例中13例に, 活動電位を大腿四頭筋に 認めた．13例中 4 例は応答時が，アキレス腱反射の応 答時より矩心波（Q1 波とする）を，7例には遅い波 （Q2 波とす）を認め，2例にはこの両者が認められた (図 $3 \mathrm{a}$ ).

応答時は $\mathrm{Q}_{1}$ 波が $17.3 \sim 21.4 \mathrm{msec}$. の範囲にあ り, $\mathrm{Q}_{2}$ 波は $28.4 \sim 40.5 \mathrm{msec}$. の範囲にあつた. 平均 応答速度で云うと $\mathrm{Q}_{1}$ 波が $56.8 \sim 71.0 \mathrm{~m} / \mathrm{sec}$ の範囲に あり,乙れは計測上の問題もあるが, T波のそれよりも 速い. $Q_{2}$ 波は25.6〜 37.0 m/secの範囲にあつた。応答 時が短く平均応答速度の速い $\mathrm{Q}_{1}$ 波は, monosynaptic と考えるのが妥当と思われるが, 応答時が長く平均応 答速度の非常に遅い $Q_{2}$ 波は polysynapticの径路が考 えられるが，これだけでは何とも云えない，同一個体 に $\mathrm{Q}_{1}$ 及び $\mathrm{Q}_{2}$ の両波が認められた 2 例で， $\mathrm{Q}_{2}$ 波の応答 時加ら $\mathrm{Q}_{1}$ 波の応答時を差引くと, 夫々 $16.2,19.1 \mathrm{msec}$. となる(図 $3 \mathrm{~b}$ ).

振巾は $\mathrm{Q}_{1}$ 波が平均 $0.11 \mathrm{mV}, \mathrm{Q}_{2}$ 波が平均 $0.2 \mathrm{mV}$ で, 同時記録したアキレス腱反射の活動電位の平均 2.04 $\mathrm{mV}$ より大分小さい. この場合, J. 氏法を行わせるとそ の大半において振巾の増大が認められた.

大腿四頭筋への放散は，脊髄反射を支配する中枢性 controlの未熟むしくは不足として, 従つてより primitiveな段階にあるあの之説明できるかあ知れない。

以上我々は, 正常児とCP児との比較に执いて,アキ レス腱反射を通じ，得られた知見を発表した。 